\title{
Kualitas Skripsi Mahasiswa Universitas Al Azhar Indonesia: Pengaruh Hasil Belajar Metodologi Penelitian dan Statistik terhadap Kualitas Skripsi
}

\author{
Zirmansyah $^{1 *}$ dan Nita Noriko ${ }^{2}$ \\ ${ }^{1}$ Fakultas Psikologi dan Pendidikan,Universitas Al Azhar Indonesia, Jl. Sisingamangaraja, Jakarta 12110 \\ Tel.7244456, fax.7233767, *email: zirmansyah@uai.ac.id \\ ${ }^{2}$ Program Studi Bioteknologi, Fakultas Sains dan Teknologi, Universitas Al Azhar Indonesia
}

Abstract - The objective of the research is to study the relationship between learning outcome on statistic, learning outcome on research methodology and thesis quality.

The research was carried out at the student Al Azhar University, with 53 samples of thesis which were selected randomly.

The research concludes there is positive correlation between: (1) learning outcome on statistics and thesis quality; (2) knowledge on research methodology and thesis quality; (3) furthermore, there is a positive correlation between learning outcome on statistcs, learning outcome on research methodology, with thesis quality.

Therefore thesis quality can be increased by improving learning outcome on statistic, and learning outcome on research metodhology.

Keywords - Learning outcome on statistics, learning outcome on research methodology and skripsi quality.

\section{LATAR BELAKANG}

$\mathrm{S}$ kripsi adalah bentuk karya ilmiah seorang mahasiswa, yang biasanya disusun sebagai salah satu persyaratan untuk mendapatkan gelar Sarjana (S1). Sebagaimana diketahui salah satu karakteristik utama pendidikan Sarjana di Indonesia adalah kesujanaan (scholarly), yakni pendidikan yang didasarkan kepada landasan ilmu pengetahuan yang berkembang, Hal ini juga berlaku di Universitas Al Azhar Indonesia (UAI), di mana seorang mahasiswa yang akan menyeleasaikan pendidikan sarjana $\left(\mathrm{S}_{1}\right)$, wajib menyusun suatu karya ilmiah berupa hasil kerja penelitian ilmiah, yang disebut skripsi.
Skripsi dikatakan karya ilmiah, karena skripsi disusun berdasarkan hasil penelitian ilmiah dan ditulis secara sistematis, konsisten dengan proses dan langkah berpikir ilmiah serta memperhatikan aturan teknik penulisan ilmiah. Koefod mengartikan skripsi sebagai karangan formal berdasarkan hasil kerja penelitian yang fungsinya adalah untuk menyampaikan suatu argumen logis yang mendukung suatu pandangan spesifik atau untuk menjawab suatu permasalahan.

Agar mahasiswa dapat menyusun skripsi, biasanya terdapat mata kuliah-mata kuliah yang menjadi prasyarat, seperti; penulisan ilmiah, Statistika dan Metodologi Penelitian. Melalui mata kuliah penulisan ilmiah seorang mahasiswa diberi bekal tentang tata cara penulisan ilmiah seperti cara mengutip buku sumber, cara menulis daftar pustaka, dan yang lebih penting melalui mata kuliah penulisan ilmiah seorang mahasiswa dapat menuangkan pemikiran logisnya secara teratur dan runtut. Melalui mata kuliah statistika seorang mahasiswa mengetahui pengumpulan data yang valid, penganalisisan data secara benar dan yang lebih penting membaca hasil analisis data yang dikaitkan dengan variabel yang diteliti. Sedangkan melalui mata kuliah metodologi penelitian mahasiswa mengerti teknik pengambilan sampel yang refresentatif, serta metodologi penelitian yang tepat, yang sesuai dengan rumusan masalah. Dengan perkataan lain, jika seorang mahasiswa telah lulus mata mata kuliah penulisan ilmiah, statistika dan metodologi penelitian, maka ia memiliki kemampuan yang cukup untuk menulis skripsi, sehingga diharapkan dia tidak mengalami kesukaran dalam menyusun skripsi, dan jika selesai skripsi yang disusunnyapun berkualitas.

Berdasarkan pengalaman membimbing skripsi, penulis sering menemukan mahasiswa yang selain kesulitan menyusun skripsi, bahkan menemukan 
permasalahan yang akan ditelitipun sampai berbulan-bulan, dan ketika ia sudah menemukan permasalahan yang akan diteliti, merumuskan masalah penelitian yang baikpun masalah salah. Ketika masalah sudah dirumuskan dengan benar, menemukan teknik analisis datapun masih kesulitan, apalagi ketika data selesai dianalisis membaca hasil analisis data serta mengkaitkannya dengan variabel penelitianpun masih sering salah, seakan-akan mata kuliah Statistika dan Metodologi Penelitian tidak berperan dalam penulisan karya ilmiah yang disebut Skripsi. Sementara kalaupun ada satu atau dua orang mahasiswa yang cepat menyusun skripsi, saat ujian skripsi sumbangan atau kontribusi mata kuliah Statistika dan Metodologi Penelitian hampir-hampir tidak signifikan.

Untuk dapat mengambil mata kuliah penulisan skripsi mahasiswa diwajibkan menempuh dan telah lulus mata kuliah metodologi penelitian dan statistika. Melalui matakuliah Metodologi Penelitian seorang mahasiswa diajarkan tentang langkah-langkah kerja penelitian, mulai dari menemukan masalah sampai kepada perumusan masalah, melakukan kajian teori, pengumpulan data, serta cara melaporkannya. Sedangkan melalui mata kuliah Statistika seseorang tahu bagaimana menganalisis data serta membaca hasil analisis data secara tepat dan benar, dan mengkaitkannya dengan variabel penelitian.

Penelitian jika dilihat dari pendekatan yang digunakan dapat dikelompokkan menjadi dua, yakni; (a) kuantitatif, dan (b) kualitatif. Mahasiswa UAI yang akan menyelesaikan pendidikannya dalam melaksanakan kegiatan penelitian dapat memilih salah satu pendekatan di atas. Namun agar dapat ditarik suatu inferensi umum tentang kualitas penelitian (Skripsi) yang disusun oleh mahasiswa, maka dalam penelitian ini, penelitian yang akan diukur kualitasnya adalah penelitian yang menggunakan pendekatan kuantitatif.

Tertarik dengan pemikiran di atas, sekaligus untuk menjawab keingintahuan, tentang keterkaitan dan kontribusi mata kuliah statistika dan mata kuliah metodologi penelitian terhadap kualitas skripsi mahasiswa UAI, maka perlu dilakukan penelitian untuk menjawab permasalahan berikut: (1) Bagaimana hasil belajar mata kuliah metodologi penelitian, (2) Bagaimana hasil belajar mata kuliah statistika, (3) Bagaimana gambaran kualitas Skripsi Mahasiswa UAI, (4) Apakah terdapat pengaruh hasil belajar metodologi penelitian terhadap Kualitas Skripsi? (5) Apakah terdapat pengaruh hasil belajar statistika terhadap Kualitas Skripsi, dan (6) Apakah terdapat pengaruh hasil belajar metodologi penelitian dan hasil belajar statistika secara bersama-sama terhadap Kualitas Skripsi?

\section{KAJIAN TEORI DAN PERUMUSAN HIPOTESIS}

\section{A. Kualitas Skripsi}

Pengertian kualitas menurut Pierre dan Simar adalah pencapaian tujuan yang telah ditetapkan sebelumnya, atau kesesuaian dengan standar yang telah ditentukan. Sedangkan Bourke, menyatakan kualitas sebagai gambaran dari suatu produk atau hasil kerja. Dengan demikian, kualitas meliputi berbagai aspek berkenaan dengan kriteria atau karakteristik hasil kerja atau kegiatan. Jika dikaitkan dengan skripsi mahasiswa, maka kulitas skripsi berkenaan dengan kriteria yang harus termuat dalam skripsi tersebut.

Hont menggunakan dua pendekatan untuk memahami arti kualitas, yakni (1) pendekatan deskriptif, dan (2) pendekatan metafisik. Pendekatan deskriptif, beranggapan bahwa kualitas adalah gambaran dan karakteristik hasil suatu pekerjaan. Dalam pendekatan ini, sesuatu yang berkualitas dipandang sebagai sesuatu yang bernilai. Pada pendekatan kedua yang disebut pendekatan metafisik, kualitas dipandang sebagai sesuatu yang tidak hanya dapat dianalisis secara deskriptif tapi juga memiliki kriteria-kriteria, sehingga dapat diukur.

Skripsi adalah bentuk karya ilmiah seorang mahasiswa, yang biasanya disusun sebagai salah satu persyaratan untuk mendapatkan gelar pada Sarjana. Skripsi dikatakan karya ilmiah, karena skripsi disusun berdasarkan hasil penelitian ilmiah dan ditulis secara sistematis, konsisten dengan proses dan langkah berpikir ilmiah serta memperhatikan aturan teknik penulisan ilmiah. Dengan demikian membicarakan kualitas Skripsi berarti membicarakan kualitas penelitian. Penelitian mempunyai peranan yang khas bila dikaitkan dengan kegiatan tertentu. Pada satu pihak, penelitian merupakan sarana edukatif bila dikaitkan dengan kegiatan pendidikan, dan di pihak lain, penelitian sangat fungsional dalam menemukan pengetahuan, atau lebih tepat lagi informasi baru.

Dalam penulisan skripsi, kualitas skripsi secara umum didekati dengan pendekatan metafisik. Hal ini disebabkan kualitas skripsi selain berkaitan erat dengan nilai yang dikandung, juga harus memenuhi kriteria yang jelas. Hal ini sejalan dengan pendapat Delors, yang mengartikan kualitas berhubungan dengan produk, atau hasil suatu kegiatan yang 
memenuhi kriteria yang telah ditentukan. Selanjutnya dikatakan bahwa terdapat tiga hal yang harus terkandung dalam hasil pekerjaan yang berkualitas yaitu; (1) keandalan, yaitu hasil pekerjaan sesuai dengan aturan yang ditetapkan dan sesuai dengan yang dijanjikan, (2) kepastian, hasil kerja sesuai dengan harapan sehingga menimbulkan kepercayaan, dan (3) bukti fisik, berkenaan kelengkapan bukti yang harus ada.

Secara istilah penelitian, diartikan sebagai suatu kegiatan yang hati-hati, sistematis, pengkajian yang sabar dalam lapangan pengetahuan, suatu kegiatan dalam upaya penemuan atau pembuktikan faktafakta dan prinsip-prinsip. Pengertian hati-hati dan sistematis yang dimaksud disini adalah, karena penelitian harus dilakukan secara teliti serta memiliki tatanan dan sistem yang telah ditetapkan sebelumnya. Dengan perkataan lain prosedur kerjanya dapat digambarkan kepada orang lain, sehingga siapapun dapat mengulangi prosedur tersebut untuk memeriksa informasi yang baru ditemukan dalam kaitannya dengan kesahihan dan reliabilitas, sebagai indikasi dari penelitian yang baik atau berkualitas.

Schulte dalam Billah, menyatakan penelitian dikatakan berkualitas, jika penelitian tersebut meliputi suatu rangkaian proses dari suatu urutan tahap-tahap beruntun yang pada garis besarnya terdiri dari tahap-tahap persiapan, pengumpulan data, penguraian dan pelaporan hasil. Maknanya bahwa tahap-tahap terdahulu dalam rangkaian kerja penelitian menjadi landasan tahap-tahap berikutnya. Sedangkan Race menyatakan penelitian dikatakan berkualitas jika penelitian tersebut memiliki validitas dan reliabilitas yang handal. Sehubungan dengan validitas penelitian, Eisenhart dan Borko, mengemukakan ada standar yang harus dipenuhi, yakni; (1) kontribusi penelitian itu terhadap pengetahuan dibidangnya, (2) kesesuaian antara masalah penelitian dengan prosedur pengumpulan data, dan teknik-teknik analisis, serta (3) dipenuhinya persyaratan kehandalan instrumen penelitian.

Skripsi sebagai suatu laporan penelitian merupakan hasil kerja ilmiah harus berkualitas, karena itu Fraenkel dan Wallen menyatakan ada empat hal yang harus ada dalam suatu laporan penelitian ilimah, yaitu; (1) bagian pengantar, (2) bagian utama, (3) sumber rujukan, dan (4) lampiran-lampiran (pelengkap). Selanjutnya dinyatakan pada bagian pengantar berisi; halaman judul, daftar isi, daftar gambar, dan daftar tabel. Sedangkan pada bagian utama, memuat lima bagian yakni; (1); masalah yang akan diteliti, di dalam bagian ini memuat, (a) tujuan penelitian, (b) manfaat dari penelitian, (c) pertanyaan dan hipotesis penelitian, serta (d) definsi-definisi istilah, (2) kajian dari teori yang relevan, (3) prosedurprosedur yang berisi (a) deskripsi dari rancangan penelitian, (b) deskripsi sampel, (c) deskripsi akan instrumen pengumpul data yang digunakan, (d) penjelasan akan prosedur yang dilakukan, (e) pembahasan akan validitas internal, dan (f) deskripsi dan justifikasi teknik statistik yang digunakan, (4) temuan-temuan, berisi uraian yang berkenaan dengan hipotesis atau pertanyaan penelitian, (5) ringkasan, kesimpulan, dan rekomendasi, serta saran.

Penelitian dengan pendekatan kuantitatif mementing kan adanya variabel-variabel sebagai obyek penelitian, variabel-variabel tersebut harus didefinisikan dalam bentuk operasionalisasi oleh karenanya variabel penelitian harus dikaji terlebih dahulu, yang disebut dengan kajian teori. Makin banyak teori yang diluas, berarti makin dalam dan makin tajam kajian teori. Selain itu reliabilitas dan validitas merupakan syarat mutlak yang harus dipenuhi dalam penelitian yang menggunakan pendekatan kuantitatif, karena terpenuhinya persyaratan tersebut akan menentukan kualitas data yang dikumpulkan dan berarti kualitas hasil penelitian.

Berdasarkan uraian-uraian di atas, dapat disimpulkan bahwa kualitas skripsi adalah kesesuaian antara skripsi mahasiswa dengan standar yang harus terdapat dalam laporan penelitian ilmiah dengan menggunakan metode dan prosedur ilmiah, yang di dalamnya memuat, permasalahan, kajian teori, hipotesis, populasi dan teknik sampling, pengujian validitas dan reliabilitas instrumen, metode penelitian, teknik analisis data, kesimpulan dan rekomendasi.

\section{B. Pengertian Hasil Belajar}

Hasil belajar adalah kemampuan seseorang mema hami dan mengerti apa-apa yang telah dipelajarinya. Dalam kegiatan belajar mengajar hasil belajar meng gambarkan hasil dari kegiatan belajar, yang diindikasikan dalam bentuk nilai atau indeks prestasi, karena itu perkataan lain hasil belajar sering juga disebut dengan daya serap, oleh karena itu untuk mendapatkan pengertian tentang daya serap perlu dijelaskan apa itu belajar.

Belajar pada dasarnya adalah perubahan tingkah laku yang relatif menetap yang dapat diperoleh, diantaranya, melalui pengalaman. Pengalaman dapat berupa interaksi dengan lingkungan eksternal dan melibatkan proses yang tidak nampak. Belajar juga merupakan perilaku aktif mahasiswa dalam 
menghadapi lingkungan untuk men dapatkan pengalaman, pengetahuan, pemahaman, dan makna. Menurut Gagne, Robert M dan Marcy, belajar merupakan kegiatan mental individu yang kompleks dan biasanya menghasilkan perubahan tingkah laku dan pola pikir pelajar, sehingga dengan adanya perubahan maka dapat dikatakan bahwa kegiatan belajar (learning) telah terjadi.

Hasil belajar adalah sebagai perubahan tingkah laku yang meliputi tiga ranah, yakni ranah kognitif, afektif, dan psikomotor. Hasil belajar adalah suatu hasil yang diharapkan dari pembelajaran yang telah ditetapkan dalam rumusan perilaku tertentu, atau hasil belajar merupakan wujud perubahan perilaku yang terjadi atas suatu obyek tertentu sebagai akibat dari proses belajarnya.

Objek hasil belajar diwujudkan dengan perubahan tingkah laku seseorang dalam ranah kognitif, afektif dan psikomotorik. Secara umum, faktor-faktor yang mempengaruhi hasil belajar adalah (1) materi atau mata kuliah yang dipelajari, (2) faktor lingkungan mahasiswa, (3) faktor instrumental, (4) keadaan individu mahasiswa, dan (5) proses belajar mengajar. Jenis mata kuliah atau materi yang dipelajari juga turut mempengaruhi proses dan hasil belajar, misalnya belajar tentang pengetahuan yang bersifat konsep berbeda dengan belajar tentang pengetahuan yang bersifat prinsip.

Hasil belajar atau daya serap dapat dikaitkan dengan terjadinya perubahan kepandaian, kecakapan, atau kemampuan seseorang, dimana proses kepandaian itu terjadi tahap demi tahap. Daya serap sebagai wujud hasil belajar diwujudkan dalam lima kemampuan yaitu keterampilan intelektual, strategi kognitif, informasi verbal, keterampilan motorik, dan sikap. Dimensi kognitif adalah kemampuan yang berhubungan dengan berpikir, mengetahui, dan memecahkan masalah seperti pengetahuan komprehensif, aplikatif, sintesis, analisis, dan pengetahuan evaluatif. Dimensi afektif adalah kemampuan yang berhubungan dengan sikap, nilai, minat, dan apresiasi. Sedangkan dimensi psikomotorik adalah kemampuan yang berhubungan dengan keterampilan motorik.

\section{Mata Pelajaran Metode Penelitian}

Arti metode penelitian atau metodologi penelitian sendiri masih ada yang keliru mengartikannya. Metode secara harfiah dapat diartikannya sebagai cara atau jalan. Dalam kaitan penelitian metode penelitian dapat diartikan sebagai cara kerja dalam memahami objek yang menjadi sasaran ilmu tersebut, sedangkan metodologi penelitian menurut Mikkelsen, mencakup teori dan tidak langsung operasional seperti metode. Hasan, dalam Koentjara ningrat mengartikan metodologi penelitian sebagai pengetahuan tentang berbagai cara kerja penelitian.

Metodologi adalah ilmu yang mempelajari metode. Margaret dan Hilda, menyatakan metodologi penelitian membahas konsep teoretik berbagai metode, mengkaji keunggulan dan kelemahannya. Metodologi merupakan merupakan sarana dan cara memperoleh pengetahuan serta pemahaman teori dari peneliti tercakup dalam istilah ini. Inti dari metodologi apapun adalah konsepsinya tentang realitas dan pengaruh atau efek sebab-akibat yang merupakan dasar bagi terciptanya pengetahuan baru berikut keabsahannya. Cara peneliti berhubungan dengan orang-orang yang diteliti dan tingkah lakunya dalam mengumpulkan informasi serta apa yang ia lakukan dengan informasi tersebut, semuanya bersumber dari konsep, khusus mengenai realitas dan efek sebab-akibat. Dengan perkataan lain, metodologi merupakan kesatuan dari filsafat dengan metode abstraksi dan metode penyidikan. Dari berbagai penjelasan di atas dapat disimpulkan bahwa metodologi penelitian adalh menyangkut ilmu dan teori dalam metode penelitian. Sedangkan metode itu sendiri menyangkut alat atau teknik melaksanakan penelitian.

Dari kedua pengertian di atas, dapat disimpulkan bahwa dalam melakukan kerja penelitian bukanlah mengkaji metodologi, melainkan memilih metode penelitian yang tepat untuk digunakan yang berfungsi memandu peneliti tentang tata urutan-urutan bagaimana penelitian itu dilaksanakan.

Dalam buku pedoman pelaksanaan penelitian dan pengabdian kepada masyarakat oleh perguruan tinggi, yang dikeluarkan oleh Litbang Dirjen Dikti, untuk penelitian yang mempergunakan pendekatan kuantitatif, yang termasuk dalam metode penelitian adalah uraian yang meliputi, variabel dalam penelitian, model yang digunakan, rancangan penelitian, teknik pengumpulan data dan analisis data, cara penafsiran dan penyimpulan hasil penelitian. Sedangkan untuk penelitian kualitatif, penjelasan pendekatan yang digunakan, proses pengumpulan dan analisis informasi, proses penafsiran dan penyimpulan hasil penelitian.

Dari uraian di atas dapat disimpulkan bahwa metodologi penelitian adalah menyangkut ilmu dan teori dalam metode penelitian. Sedangkan metode penelitian itu sendiri menyangkut alat atau teknik melaksanakan penelitian. Ini berarti dapat juga dikatakan bahwa dalam melaksanakan penelitian bukan mengkaji metodologi, melainkan 
sebagaimana yang dinyatakan oleh Hans, yakni memilih metode penelitian yang akan digunakan, yang memandu peneliti tentang bagaimana uruturutan penelitian itu dilaksanakan. Selanjutnya dikatakan, terdapat tiga hal yang harus dibedakan dalam membicarakan metode penelitian, yakni; (1) metode itu sendiri, (2) prosedur, dan (3) teknik mengumpulkan data. Metode sebagaimana yang dijelaskan di atas adalah urut-urutan bagaimana penelitian dilaksanakan, prosedur merupakan urutan pekerjaan yang harus dilaksanakan, sedangkan teknik menyangkut alat-alat yang diperlukan untuk mengumpulkan data.

Dari uraian di atas dapat ditarik kesimpulan bahwa, yang menjadi muatan metodologi penelitian adalah hal-hal yang berkaitan dengan, tujuan penelitian, populasi dan teknik sampling, prosedur penelitian, teknik dan alat pengumpulan data, teknik dan alat analisis data. Dengan demikian, maka yang dimaksud dengan pengetahuan metodologi penelitian adalah metode-metode yang ditempuh peneliti atau pendekatan yang digunakan dalam mempelajari gejala-gejala alam dan sosial dalam menemukan jawaban permasalahan kehidupan dan upaya penemuan kebenaran.

Berdasarkan beberapa teori yang telah dikemukakan di atas dapat disimpulkan bahwa yang dimaksud dengan metodologi penelitian di sini adalah daya serap mahasiswa terhadap mata kuliah metode penelitian terdiri dari berbagai pokok bahasan seperti; (1) populasi dan teknik sampling, (2) hipotesis, (3) variabel, (4) metode dan teknik pengumpulan data, (5) instrumentasi, validitas dan reliabilitas, (6) teknik analisis data, (7) jenis-jenis metode penelitian itu sendiri.

\section{Mata Pelajaran Statistika}

Beragam pendapat statistikawan tentang Statistika. Ada yang mengatakan statistika adalah logika atau akal sehat (common sense), yang disertai dengan prosedur-prosedur aritmatika. Pendapat lain mengatakan statistika adalah ilmu pengetahuan, murni dan terapan mengenai penciptaan, pengembangan, dan penerapan teknikteknik sedemikian rupa sehingga ketidak pastian inferensial induktif dapat diperhitungkan. Pengertian yang disepakati secara umum tentang statistika adalah, ilmu yang mempelajaru cara pengumpulan data, pengolahan, penyajian dan analisis data serta cara pengambilan keputusan.

Dalam kegiatan penelitian salah satu pendekatan atau metode penelitian yang sering digunakan adalah metode penelitian kuantitatif. Statistika adalah teknik analisis data yang sering digunakan dalam melakukan analisis data hasil penelitian kuantitatif. Permasalahannya materi-materi statistika yang diajarkan di kelas dan buku-buku statistika hanya membahas tentang statistika saja tanpa menghubungkannya dengan penelitian, yang diajarkan adalah bagaimana menghitung mean, median, modus, menguji hipotesis dengan t-test, $\mathrm{F}$ test, anova, dan sebagainya, penekannya adalah "bagaimana menghitung" bukannya "bagaimana menggunakannya dalam melakukan analisis data hasil penelitian.

Dalam GBPP tujuan pembelajaran statistika adalah:

1) Melatih cara berpikir dan bernalar dalam menarik kesimpulan, misalnya melalui kegiatan penyelidikian, eksplorasi, eksperimen, menunjukkan kesamaan, perbedaan, konsisten dan inkonsistensi.

2) Mengembangkan aktivitas kreatif yang melibatkan imajinasi, intuisi, dan penemuan dengan mengembangkan pemikiran divergen, orisinil, rasa ingin tahu, membuat prediksi dan dugaan, serta mencoba-coba.

3) Mengembangkan kemampuan memecahkan masalah.

4) Mengembangkan kemampuan menyampaikan informasi atau mengkomunikasikan gagasan antara lain melalui pembicaraan lisan, grafik, peta, diagram, dalam menjelaskan gagasan, dan

5) Membiasakan untuk mengambil atau membuat keputusan secara tepat.

6) Melatih mahasiswa dalam melakukan analisis data hasil penelitian, serta menafsirkannya secara tepat.

Berdasarkan uraian di atas, diketahui bahwa mata pelajaran statistika erat kaitannya dan besar sumbangan dalam kerja penelitian, khususnya penelitian kuantitatif. Atau dengan perkataan lain, kualitas penelitian terutama dalam kaitan analisis data dan interpretasi hasil analisis data skripsi sangat tergantung kepada sejauh mana penguasaan seseorang peneliti terhadap mata pelajaran Statistika. Atau dengan perkataan lain, makin baik penguasaan mahasiswa terhadap mata kuliah statistika, maka skripsi yang disusun mahasiswa akan semakin berkualitas.

\section{Perumusan Hipotesis}

Berdasarkan kajian teori dan kerangka berpikir di atas, maka dapat dirumuskan hipotesis penelitian sbb:

1. Terdapat pengaruh Indeks Prestasi (daya serap) mata kuliah Statistika terhadap Kualitas Skripsi? 
2. Terdapat pengaruh Indeks Prestasi (daya serap) mata kuliah Metode Penelitian terhadap Kualitas Skripsi?

3. Terdapat pengaruh Indeks Prestasi (daya serap) mata kuliah Statistika dan Mata Kuliah Metode Penelitian secara bersama-sama terhadap Kualitas Skripsi?

\section{TEMUAN HASIL PENELITIAN}

\section{A. Deskripsi Data Hasil Penelitian}

\section{Gambaran Nilai mahasiswa berdasarkan mata kuliah}

Dalam temuan hasil penelitian, selain akan disajikan analisis data yang bertujuan menjawab rumusan masalah penelitian atau menguji hipotesis penelitian, juga akan dideskripsikan temuan yang berupa gambaran daya serap atau hasil belajar (indeks prestasi), mahasiswa terhadap mata kuliah metodologi penelitian, statistika dan indeks prestasi (nilai) skripsi mahasiswa UAI yang terdapat dalam SIA UAI. Melalui penyajian nilai dapat digambarkan bagaimana hasil belajar mata kuliah metodologi penelitian dan statistika yang telah berlangsung selama ini, untuk kelima program studi penelitian. Selangkapnya gambaran nilai dan gradenya dapat dilihat dalam tabel 1, sampai dengan tabel 3, di bawah ini.

Tabel 1. Distribusi Nilai Matakuliah Metodologi Penelitian berdasarkan Program Studi

\begin{tabular}{|c|c|c|c|c|c|c|c|c|}
\hline \multirow{2}{*}{$\begin{array}{l}\mathbf{N} \\
\mathbf{o}\end{array}$} & \multirow{2}{*}{$\begin{array}{c}\text { Program } \\
\text { Studi }\end{array}$} & \multirow{2}{*}{$\begin{array}{l}\text { Nama } \\
\text { Mata } \\
\text { Kuliah }\end{array}$} & \multicolumn{5}{|c|}{ Sebaran Nilai $(\%)$} & \multirow{2}{*}{$\Sigma$} \\
\hline & & & $\mathbf{A}$ & B & C & D & E & \\
\hline 1. & PAUD & Metlit & $\begin{array}{c}26 \\
(31) \\
\end{array}$ & $\begin{array}{c}55 \\
(66) \\
\end{array}$ & $\begin{array}{c}1 \\
(1) \\
\end{array}$ & $\begin{array}{c}0 \\
(0) \\
\end{array}$ & $\begin{array}{c}2 \\
(2) \\
\end{array}$ & 84 \\
\hline 2. & H. K. & $\begin{array}{l}\text { Metlit } \\
\text { Dakwah }\end{array}$ & $\begin{array}{c}38 \\
(40)\end{array}$ & $\begin{array}{c}51 \\
(54)\end{array}$ & $\begin{array}{c}6 \\
(6)\end{array}$ & $\begin{array}{c}0 \\
(0)\end{array}$ & $\begin{array}{c}0 \\
(0)\end{array}$ & 95 \\
\hline 3. & Ilkom & $\begin{array}{l}\text { Metlit } \\
\text { Sosial }\end{array}$ & $\begin{array}{c}98 \\
(20) \\
\end{array}$ & $\begin{array}{l}245 \\
(50) \\
\end{array}$ & $\begin{array}{r}92 \\
(19) \\
\end{array}$ & $\begin{array}{l}19 \\
\text { (4) } \\
\end{array}$ & $\begin{array}{l}38 \\
(7) \\
\end{array}$ & 492 \\
\hline 4. & $\begin{array}{l}\text { Manaje } \\
\text { men }\end{array}$ & Metlit & $\begin{array}{c}55 \\
(41) \\
\end{array}$ & $\begin{array}{c}41 \\
(30) \\
\end{array}$ & $\begin{array}{r}22 \\
(16) \\
\end{array}$ & $\begin{array}{c}1 \\
(1)\end{array}$ & $\begin{array}{c}16 \\
(12)\end{array}$ & 135 \\
\hline 5. & T. Industri & $\begin{array}{l}\text { Komuni } \\
\text { kasi } \\
\text { Profesio } \\
\text { nal/ Met } \\
\text { Riset }\end{array}$ & $\begin{array}{c}3 \\
(18)\end{array}$ & $\begin{array}{c}10 \\
(59)\end{array}$ & $\begin{array}{c}2 \\
(12)\end{array}$ & $\begin{array}{c}0 \\
(0)\end{array}$ & $\begin{array}{c}2 \\
(11)\end{array}$ & 17 \\
\hline & \multicolumn{2}{|c|}{ Jumlah (\%) } & $\begin{array}{l}283 \\
(29)\end{array}$ & $\begin{array}{l}469 \\
(49) \\
\end{array}$ & $\begin{array}{l}138 \\
(14) \\
\end{array}$ & $\begin{array}{l}22 \\
(3) \\
\end{array}$ & $\begin{array}{l}58 \\
(6)\end{array}$ & 970 \\
\hline
\end{tabular}

Berdasarkan tabel 1, di atas diketahui bahwa terdapat perbedaan penamaan nama mata kuliah "metodologi penelitian" antar program studi. Kata metodologi penelitian muncul pada program studi PAUD dan Ilmu Manajemen, sedangkan untuk prodi HK, diberi nama metodologi penelitian dakwah, meskipun ketika dilihat SAP nya, adalah sama dengan SAP PAUD. Pembedaan penamaan nama mata kuliah antar prodi yang dalam satu fakultas, tentunya berpengaruh pada pengkodean dalam SIA UAI, dan berimplikasi tidak efisien. Dari tabel 4.1, di atas diketahui bahwa secara keseluruhan (populasi) nilai metodologi penelitian mahasiswa mayoritas adalah "B" sebanyak 469 orang atau $49 \%$, diikuti oleh nilai " $A$ " sebanyak 283 orang atau 29\%, meskipun demikian masih terdapat mahasiswa yang mendapatkan nilai " $\mathrm{C}$ ", "D", dan "E", masing-masing 14, 3, dan $6 \%$.

Berdasarkan program studi, program studi yang mahasiswanya mendapatkan nilai " $A$ " terbanyak adalah Ilmu Manajemen, sebanyak 41\%, diikuti oleh HK " $40 \%$ ", PAUD " $26 \%$ ". Sedangkan program studi yang mahasis wanya mendapatkan nilai " $A$ " terkecil adalah Teknik Industri sebesar $18 \%$. Sedangkan program studi yang mahasiswanya mendapatkan nilai "E" dimulai dari yang terbanyak adalah (1) Manajemen, (2) Teknik Industri, (3) Ilkom dan (4) PAUD. Bagaimana nilai mahasiswa untuk mata kuliah statistika dapat dilihat dalam tabel 2 .

Tabel 2. Distribusi Nilai Matakuliah Statistika berdasarkan Program Studi

\begin{tabular}{|c|c|c|c|c|c|c|c|}
\hline \multirow{2}{*}{$\begin{array}{l}\mathbf{N} \\
\mathbf{0}\end{array}$} & \multirow{2}{*}{$\begin{array}{c}\text { Program } \\
\text { Studi }\end{array}$} & \multirow{2}{*}{$\begin{array}{c}\text { Mata } \\
\text { Kuliah }\end{array}$} & \multicolumn{5}{|c|}{ Sebaran Nilai $(\%)$} \\
\hline & & & A & B & $\mathrm{C}$ & D & $\mathbf{E}$ \\
\hline 1. & PAUD & $\begin{array}{l}\text { Statistik } \\
\text { Pendidikan }\end{array}$ & $\begin{array}{c}33 \\
(29)\end{array}$ & $\begin{array}{c}70 \\
(62) \\
\end{array}$ & $\begin{array}{c}2 \\
(2)\end{array}$ & $\begin{array}{c}3 \\
(3)\end{array}$ & $\begin{array}{c}5 \\
(4) \\
\end{array}$ \\
\hline 2. & H. K. & Statistik & $\begin{array}{c}43 \\
(37)\end{array}$ & $\begin{array}{c}58 \\
(50)\end{array}$ & $\begin{array}{l}11 \\
(9)\end{array}$ & $\begin{array}{c}1 \\
(1)\end{array}$ & $\begin{array}{c}4 \\
\text { (3) }\end{array}$ \\
\hline 3. & T. Industri & $\begin{array}{l}\text { Statistika } \\
\text { Industri }\end{array}$ & $\begin{array}{c}24 \\
(35)\end{array}$ & $\begin{array}{c}34 \\
(50)\end{array}$ & $\begin{array}{c}7 \\
(10)\end{array}$ & $\begin{array}{c}3 \\
(4)\end{array}$ & $\begin{array}{c}1 \\
(1)\end{array}$ \\
\hline 4. & $\begin{array}{l}\text { Manaje } \\
\text { men }\end{array}$ & $\begin{array}{l}\text { Statistik1 } \\
\text { dan } 2\end{array}$ & $\begin{array}{c}29 \\
(14)\end{array}$ & $\begin{array}{c}57 \\
(27)\end{array}$ & $\begin{array}{c}86 \\
(40)\end{array}$ & $\begin{array}{c}28 \\
(13)\end{array}$ & $\begin{array}{l}15 \\
\text { (7) }\end{array}$ \\
\hline 5. & Ilkom & $\begin{array}{l}\text { Pengantar } \\
\text { Statistik } \\
\text { Sosial } \\
\end{array}$ & $\begin{array}{l}223 \\
(24)\end{array}$ & $\begin{array}{l}240 \\
(26)\end{array}$ & $\begin{array}{l}238 \\
(26)\end{array}$ & $\begin{array}{l}122 \\
(13)\end{array}$ & $\begin{array}{c}11 \\
(12)\end{array}$ \\
\hline & \multicolumn{2}{|c|}{ Jumlah (\%) } & $\begin{array}{l}393 \\
(25)\end{array}$ & $\begin{array}{l}509 \\
(32)\end{array}$ & $\begin{array}{l}380 \\
(24)\end{array}$ & $\begin{array}{l}163 \\
(10)\end{array}$ & $\begin{array}{l}140 \\
\text { (9) }\end{array}$ \\
\hline
\end{tabular}

Penamaan untuk mata kuliah statistikapun antar program studi juga berbeda. Ada yang memberi nama "statistic", dan ada juga yang memberi nama "statistika". Perbedaan nomenklatur mata kuliah statistika tentunya tidak efektif karena itu sesuai peraturan pemerintah ke depan perlu menyamakan nomen klatur mata kuliah statistika. Dari tabel 2, di atas diketahui bahwa secara keseluruhan (populasi) nilai metodologi penelitian mahasiswa mayoritas adalah "B" sebanyak 509 orang 32\%, diikuti oleh nilai " $A$ " sebanyak 393 orang $25 \%$, dan nilai "C" sebanyak 380 orang (24\%.) Meskipun demikian masih terdapat mahasiswa yang mendapatkan nilai "D", dan "E", masing-masing 10\%, dan $9 \%$.

Berdasarkan program studi, program studi yang mahasiswanya mendapatkan nilai " $A$ " terbanyak adalah Healing Konseling, sebanyak 37\%, diikuti oleh T. Industri “35\%”, PAUD “29\%”. Sedangkan program studi yang mahasiswanya mendapatkan 
nilai "A" terkecil adalah Ilkom, Manajemen dan Ilkom, masing-masing sebesar $14 \%$ dan $24 \%$.

Tabel 3. Distribusi Nilai Skripsi (tugas akhir) berdasarkan Program Studi

\begin{tabular}{|l|l|c|c|c|c|}
\hline \multirow{2}{*}{ No } & \multirow{2}{*}{$\begin{array}{c}\text { Program } \\
\text { Studi }\end{array}$} & \multicolumn{3}{|c|}{ Sebaran Nilai (\%) } & \multirow{2}{*}{ Jum } \\
\cline { 3 - 5 } & & $\mathbf{A}(\boldsymbol{\%})$ & $\mathbf{B}(\boldsymbol{\%})$ & $\begin{array}{c}\text { C } \\
\text { lah }\end{array}$ & \\
\hline 1. & PAUD & $12(41)$ & $17(59)$ & 0 & 29 \\
\hline 2. & H. K. & $28(56)$ & $22(44)$ & 0 & 50 \\
\hline 3. & Ilkom & $98(51)$ & $92(48)$ & 2 & 192 \\
\hline 4. & Manajemen & $7(30)$ & $14(61)$ & $2(8)$ & 23 \\
\hline 5. & T. Industri & $20(63)$ & $12(38)$ & & 32 \\
\hline & Jumlah & 165 & 157 & 4 & 326 \\
\cline { 2 - 5 } & Jumlah (\%) & 51 & 48 & 1 & 100 \\
\hline
\end{tabular}

Untuk nilai skripsi sebagaimana terdapat dalam tabel 3, dari 326 skripsi yang dianalisis diketahui secara keseluruhan mayoritas nilai skripsi mahasiswa UAI adalah "A" sebanyak 165 orang atau $51 \%, 157$ orang atau $48 \%$ mendapatkan nilai "B". meskipun demikian terdapat 4 orang atau $8 \%$, yang mendapatkan nilai "C". Sesuai dengan pedoman yang berlaku bahwa nilai skripsi minimal adalah "B", maka nilai " $C$ " berarti tidak lulus atau mahasiswa tersebut kembali diuji ulang. Cukup besar prosentase mahasiswa yang mendapatkan nilai "C", perlu mendapatkan perhatian yang serius. Beragam faktor yang memungkinkan seorang mahasiswa tidak lulus dalam ujian skripsi, antara lain; ketidakseriusan dalam menyusun skripsi, terlalu tegang "stress" saat ujian karena kurang persiapan, atau pelaksanaan bimbingan yang kurang intensif karena sulit berkomunikasi dengan dosen atau memang karena kemalasan si mahasiswa itu sendiri, serta faktor-faktor lainnya.

\section{Indeks prestasi berdasarkan program studi untuk ketiga mata kuliah}

Bagaimana indeks prestasi mahasiswa UAI berdasarkan program studi dan untuk setiap mata kuliah (metodologi penelitian, statistika dan skripsi), dapat dilihat dari tabel 4 , di bawah ini.

Tabel 4. Indeks Prestasi Rata-Rata untuk tiga mata kuliah

\begin{tabular}{|c|l|c|c|c|}
\hline N & \multirow{2}{*}{$\begin{array}{c}\text { Program } \\
\text { o }\end{array}$} & \multicolumn{1}{|c|}{ Studi } & \multicolumn{3}{|c|}{ Nama Mata Kuliah } \\
\cline { 3 - 5 } 1. & PAUD & 3,27 & 3,13 & 3,41 \\
\hline 2. & H. K. & 3,31 & 3,15 & 3,56 \\
\hline 3. & Ilkom & 2,68 & 2,36 & 3,42 \\
\hline 4. & Manajemen & 2,67 & 2,27 & 3,16 \\
\hline 5. & T. Industri & 2,68 & 3,12 & 3,67 \\
\hline & IP Rata-Rata & 2,79 & 2,59 & 3,44 \\
\hline
\end{tabular}

Dari tabel 4, diketahui dari tiga mata kuliah, nilai rata-rata tertinggi adalah untuk mata kuliah Skripsi, sedangkan yang terendah adalah untuk mata kuliah statistika. Sedangkan nilai rata-rata atau indeks prestasi tertinggi berdasarkan mata kuliah dan program studi adalah skripsi untuk program studi T Industri sebesar 3,67, dan yang terendah adalah nilai (indeks prestasi) statistika untuk program studi manajemen. Jika dibandingkan antara nilai rata-rata (indeks prestasi) rata-rata permata kuliah, program studi yang indeks prestasinya di bawah rata-rata, untuk mata kuliah metodologi penelitian adalah program studi Ilkom, Manajemen dan $\mathrm{T}$ Industri, untuk mata kuliah statistika prodi yang nilai rata-ratanya di bawah rata-rata universitas adalah Manajemen dan Ilkom, sedangkan untuk skripsi adalah PAUD, Ilkom dan Manajemen.

Dari tabel 4, juga diketahui bahwa ternyata nilai rata-rata (indeks prestasi) skripsi lebih besar dibandingkan dengan indeks prestasi rata-rata metodologi penelitian dan statistika.

\section{B. Analisis Inferensial}

Melalui analisis inferensial ingin di jawab, apakah terdapat korelasi antara nilai (indeks prestasi) metodologi penelitian, statistika dengan skripsi, dapat dilihat dalam tabel 5, di bawah ini.

Tabel 5. Statistik dan Mata kuliah yang terdapat dalam SIA UAI.

\begin{tabular}{|l|c|c|c|}
\hline \multirow{2}{*}{ Statistik } & \multicolumn{3}{|c|}{ Mata Kuliah } \\
\cline { 2 - 4 } & $\begin{array}{c}\text { Metodologi } \\
\text { Penelitian }\end{array}$ & Statistika & Skripsi \\
\hline Jumlah Data & 326 & 326 & 326 \\
\hline Nilai (IP) & 2,79 & 2,59 & 3.44 \\
\hline Sdevi & 0,75 & 0.91 & 0.58 \\
\hline Varians & 0,56 & 0.83 & 0.33 \\
\hline Korelasi & 0,16 & 0,14 & 0,17 \\
\hline \multicolumn{4}{|c|}{ Korelasi secara bersama } \\
\hline
\end{tabular}

Pertanyaan yang ingin dijawab dari penelitian ini adalah, apakah ada hubungan antara nilai (daya serap) mata pelajaran metodologi penelitian dan mata pelajaran statistika dengan nilai skripsi, dapat dilihat dari tabel 5, di atas.

Dari tabel 5, di atas diketahui harga koefisien korelasi antara mata pelajaran metodologi penelitian dengan nilai skripsi rendah dan tidak signifikans $\left(\mathrm{r}_{\mathbf{x} 1 \mathbf{y}}=0,16\right)$. Artinya bagaimanapun hasil belajar (daya serap) mahasiswa terhadap mata pelajaran metodologi penelitian ternyata tidak berkorelasi secara nyata dengan nilai skripsi, demikian juga untuk harga koefisien korelasi antar 
mata pelajaran statistika dengan skripsi sebesar $\left(\mathrm{r}_{\mathrm{x} 2 \mathrm{y}}=0,14\right)$, yang juga dalam kategori rendah dan tidak signifikans. Sedangkan harga koefisien korelasi secara bersama sama antara daya serap mahasiswa terhadap mata kuliah metodologi penelitian dan statistika dengan skripsi diperoleh harga koefisien korelasi sebesar 0,17. Harga koefisien korelasi ini meskipun positif tetapi termasuk dalam kategori rendah dan tidak signifikans.

Pertanyaan yang juga ingin di jawab adalah, mana yang lebih besar sumbangan daya serap mata kuliah metodologi penelitian atau daya serap mata kuliah statistika terhadap skripsi.

Dari tabel 5, di atas jika dibandingkan sumbangan antara mata kuliah metodologi penelitian dan mata kuliah statistika, mana yang lebih besar korelasinya ternyata harga koefisien korelasi antara mata kuliah metodologi penelitian dengan skripsi lebih besar dibandingkan harga koefisien korelasi antara mata kuliah statistika dengan skripsi $(0,17>0,14)$.

\section{Analisis Kualitias Skripsi}

Untuk mengukur kualitas digunakan pedoman penilaian skripsi, yang diturunkan dari sintesis kajian teori. Terdapat 14 indikator yang digunakan untuk menilai kualitas skripsi yaitu:

1) Rumusan Masalah mengkaitkan Variabel

2) Teori menggunakan sumber utama

3) Di akhir kajian teori dilakukan sintesis

4) Hipotesis menjawab rumusan masalah

5) Populasi dideskripsikan

6) Teknik sampling dideskripsikan

7) Instrumen penelitian diturunkan dari sintesis teori

8) Terdapat kisi-kisi Instrumen

9) Validitas dan Reliabilitas diuji

10) Harga koefisien Reliabilitas instrument dinyatakan

11) Persyaratan analisis data dideskripsikan

12) Kesimpulan menjawab rumusan masalah

13) Saran sesuai dengan temuan penelitian

Untuk melakukan analisis terhadap skripsi mahasiswa diambil 53 skripsi yang disususn secara kuantitatif sebagaimana tampak dalam tabel 6 , di bawah.
Tabel 6. Data skripsi yang dianalisis berdasarkan program studi

\begin{tabular}{|l|c|c|c|c|}
\hline Program Studi & Jumlah & $\%$ & Kumulatif $\%$ & Total \\
\hline $\begin{array}{l}\text { Healing } \\
\text { Konseling }\end{array}$ & 6 & 11.3 & 11.3 & 6 \\
\hline Ilkom & 16 & 30.2 & 41.5 & 16 \\
\hline Manajemen & 16 & 30.2 & 71.7 & 16 \\
\hline PAUD & 12 & 22.6 & 94.3 & 12 \\
\hline Teknik Industri & 3 & 5.7 & 100.0 & 3 \\
\hline
\end{tabular}

Tabel 7. Tabulasi Silang silang Prodi dan Tahun angkatan masuk mahasiswa

\begin{tabular}{|l|c|c|c|c|c|c|}
\hline \multirow{2}{*}{$\begin{array}{l}\text { Program } \\
\text { Studi }\end{array}$} & \multicolumn{7}{|c|}{ Tahun masuk mahasiswa } & \multirow{2}{*}{ Total } \\
\cline { 2 - 7 } & 2001 & 2002 & 2003 & 2004 & 2005 & \\
\hline $\begin{array}{l}\text { Healing } \\
\text { Konseling }\end{array}$ & 3 & 0 & 0 & 1 & 2 & 6 \\
\hline Ilkom & 0 & 9 & 4 & 3 & 0 & 16 \\
\hline Manajemen & 8 & 6 & 2 & 0 & 0 & 16 \\
\hline PAUD & 0 & 4 & 5 & 3 & 0 & 12 \\
\hline $\begin{array}{l}\text { Teknik } \\
\text { Industri }\end{array}$ & 0 & 2 & 1 & 0 & 0 & 3 \\
\hline Total & 19 & 19 & 2 & 1 & 12 & 53 \\
\hline
\end{tabular}

Bagaimana kualitas skripsi mahasiswa berdasarkan 14 aspek di atas dapat dilihat dalam tabel 8, sampai dengan tabel 20, di bawah ini.

Tabel 8. Rumusan Masalah mengkaitkan Variabel

\begin{tabular}{|l|c|c|c|}
\hline \multicolumn{1}{|c|}{ Pertanyaan } & Frek & $\%$ & $\begin{array}{c}\text { Prosentase } \\
\text { Kumulatif }\end{array}$ \\
\hline Tidak & 2 & 3.8 & 3.8 \\
\hline Ya dan jelas & 3 & 5.7 & 9.4 \\
\hline Ya dan Sangat & 48 & 90.6 & 100.0 \\
\hline
\end{tabular}

Tabel 9. Teori menggunakan sumber utama

\begin{tabular}{|l|c|c|c|}
\hline \multicolumn{1}{|c|}{ Pertanyaan } & Frek & $\%$ & $\begin{array}{c}\text { Prosentase } \\
\text { Kumulatif }\end{array}$ \\
\hline Tidak & 5 & 9.4 & 9.4 \\
\hline Ya Jelas & 29 & 54.7 & 64.2 \\
\hline Ya dan Sangat Jelas & 19 & 35.8 & 100.0 \\
\hline
\end{tabular}

Tabel 10. Di akhir kajian teori dilakukan sintesis

\begin{tabular}{|l|c|c|c|}
\hline \multicolumn{1}{|c|}{ Pertanyaan } & Frek & $\%$ & $\begin{array}{c}\text { Prosentase } \\
\text { Kumulatif }\end{array}$ \\
\hline Tidak & 14 & 26.4 & 26.4 \\
\hline Ya dan Jelas & 9 & 17.0 & 43.4 \\
\hline Ya dan Sangat Jelas & 30 & 56.6 & 100.0 \\
\hline
\end{tabular}


Tabel 11. Hipotesis menjawab rumusan masalah

\begin{tabular}{|l|c|c|c|}
\hline \multicolumn{1}{|c|}{ Pertanyaan } & Frek & $\%$ & $\begin{array}{c}\text { Prosentase } \\
\text { Kumulatif }\end{array}$ \\
\hline Tidak & 14 & 26.4 & 26.4 \\
\hline Ya dan Jelas & 2 & 3.8 & 30.2 \\
\hline Ya dan Sangat Jelas & 37 & 69.8 & 100.0 \\
\hline
\end{tabular}

Tabel 12. Populasi dideskripsikan

\begin{tabular}{|l|c|c|c|}
\hline \multicolumn{1}{|c|}{ Pertanyaan } & Frek & $\boldsymbol{\%}$ & $\begin{array}{c}\text { Prosentase } \\
\text { Kumulatif }\end{array}$ \\
\hline Tidak dideskripsikan & 8 & 15.1 & 15.1 \\
\hline Jelas dideskripsikan & 9 & 17.0 & 32.1 \\
\hline $\begin{array}{l}\text { Dideskripsikan dengan } \\
\text { Sangat Jelas }\end{array}$ & 36 & 67.9 & 100.0 \\
\hline
\end{tabular}

Tabel 13. Teknik sampling dideskripsikan

\begin{tabular}{|l|c|c|c|}
\hline \multicolumn{1}{|c|}{ Pertanyaan } & Frek & $\boldsymbol{\%}$ & $\begin{array}{c}\text { Prosentase } \\
\text { Kumulatif }\end{array}$ \\
\hline Tidak dideskripsikan & 9 & 17.0 & 17.0 \\
\hline Jelas dideskripsikan & 7 & 13.2 & 30.2 \\
\hline $\begin{array}{l}\text { Dideskripsikan dengan } \\
\text { Sangat Jelas }\end{array}$ & 37 & 69.8 & 100.0 \\
\hline
\end{tabular}

Tabel 14. Instrumen penelitian diturunkan dari Teori

\begin{tabular}{|l|c|c|c|}
\hline \multicolumn{1}{|c|}{ Pertanyaan } & Frek & $\%$ & $\begin{array}{c}\text { Prosentase } \\
\text { Kumulatif }\end{array}$ \\
\hline Tidak & 16 & 30.2 & 30.2 \\
\hline Ya dan Jelas & 8 & 15.1 & 45.3 \\
\hline Ya dan Sangat Jelas & 29 & 54.7 & 100.0 \\
\hline
\end{tabular}

Tabel 15. Terdapat kisi-kisi Instrumen

\begin{tabular}{|l|c|c|c|}
\hline \multicolumn{1}{|c|}{ Pertanyaan } & Frek & $\%$ & $\begin{array}{c}\text { Prosentase } \\
\text { Kumulatif }\end{array}$ \\
\hline Tidak terdapat & 33 & 62.3 & 62.3 \\
\hline Ya dan Jelas & 2 & 3.8 & 66.0 \\
\hline $\begin{array}{l}\text { Sangat Jelas terdapat } \\
\text { dalam skripsi }\end{array}$ & 18 & 34.0 & 100.0 \\
\hline
\end{tabular}

Tabel 16. Validitas dan Reliabilitas diuji

\begin{tabular}{|l|c|c|c|}
\hline \multicolumn{1}{|c|}{ Pertanyaan } & Frek & $\boldsymbol{\%}$ & $\begin{array}{c}\text { Prosentase } \\
\text { Kumulatif }\end{array}$ \\
\hline Tidak diuji & 17 & 32.1 & 32.1 \\
\hline Ya dan Jelas diuji & 4 & 7.5 & 39.6 \\
\hline Ya dan Sangat Jelas & 32 & 60.4 & 100.0 \\
\hline
\end{tabular}

Tabel 17. Harga koefisien Reliabilitas instrument dinyatakan

\begin{tabular}{|c|c|c|}
\hline $\begin{array}{c}\text { Harga Koefisien } \\
\text { Reliabilitas Instrumen }\end{array}$ & Frek & \% \\
\hline 0,00 & 33 & 62.3 \\
\hline 0,48 & 2 & 3.8 \\
\hline 0,60 & 2 & 3.8 \\
\hline 0.69 & 1 & 1.9 \\
\hline 0,73 & 1 & 1.9 \\
\hline 0,75 & 1 & 1.9 \\
\hline 0,76 & 2 & 3.8 \\
\hline 0,78 & 2 & 3.8 \\
\hline 0,81 & 2 & 3.8 \\
\hline 0,83 & 3 & 5.7 \\
\hline 0,89 & 1 & 1.9 \\
\hline 0,93 & 1 & 1.9 \\
\hline 0,96 & 2 & 3.8 \\
\hline
\end{tabular}

Tabel 18. Persyaratan analisis data dideskripsikan

\begin{tabular}{|l|c|c|c|}
\hline \multicolumn{1}{|c|}{ Pertanyaan } & Frek & $\boldsymbol{\%}$ & $\begin{array}{c}\text { Prosentase } \\
\text { Kumulatif }\end{array}$ \\
\hline Tidak dideskripsikan & 25 & 47.2 & 47.2 \\
\hline Jelas dideskripsikan & 8 & 15.1 & 62.3 \\
\hline $\begin{array}{l}\text { Dideskripsikan dengan } \\
\text { Sangat Jelas }\end{array}$ & 20 & 37.7 & 100.0 \\
\hline
\end{tabular}

Tabel 19. Kesimpulan menjawab rumusan masalah

\begin{tabular}{|l|c|c|c|}
\hline \multicolumn{1}{|c|}{ Pertanyaan } & Frek & $\boldsymbol{\%}$ & $\begin{array}{c}\text { Kumulatif } \\
\mathbf{\%}\end{array}$ \\
\hline Tidak & 5 & 9.4 & 9.4 \\
\hline Jelas menjawab & 4 & 7.5 & 17.0 \\
\hline Sangat Jelas menjawab & 44 & 83.0 & 100.0 \\
\hline
\end{tabular}

Tabel 20. Saran sesuai dengan temuan penelitian

\begin{tabular}{|l|c|c|c|}
\hline \multicolumn{1}{|c|}{ Pertanyaan } & Frek & $\boldsymbol{\%}$ & $\begin{array}{c}\text { Kumulatif } \\
\mathbf{\%}\end{array}$ \\
\hline Tidak Sesuai & 2 & 3.8 & 3.8 \\
\hline Sesuai & 18 & 34.0 & 37.7 \\
\hline Sangat Sesuai & 33 & 62.3 & 100.0 \\
\hline
\end{tabular}

\section{KESIMPULAN, DAN SARAN}

\section{A. Kesimpulan}

1) Mayoritas hasil belajar metodologi penelitian termasuk dalam kateori "baik" (nilai B)

2) Mayoritas hasil belajar statistika termasuk dalam kateori "baik" (nilai B) 
3) Mayoritas skripsi mahasiswa UAI adalah "Sangat Baik (nilai "A")

4) Tidak terdapat pengaruh hasil belajar metodologi penelitian terhadap kualitas skripsi, hal ini karena sumbangan hasil belajar metodologi penelitian terhadap kualitas skripsi sebesar $2,56 \%$.

5) Tidak terdapat pengaruh hasil belajar terhadap kualitas skripsi, hal ini karena sumbangan hasil belajar statistika terhadap kualitas skripsi sebesar 1,96\%.

6) Sumbangan nilai mata kuliah metodologi penelitian terhadap kualitas skripsi lebih besar dibandingkan sumbangan nilai mata kuliah statistika terhadap skripsi

\section{B. Saran}

Untuk meningkatkan sumbangan mata kuliah meto dologi penelitian dan mata kuliah statistika terhadap kemampuan mahasiswa menulis skripsi, agar skripsi mahasiswa UAI berkualitas dapat dilakukan dengan cara:

1) Pembelajaran metodologi penelitian dan statistika ditekankan pada analisis kasuskasus penelitian yang pernah dan sudah dilakukan oleh orang lain,

2) Dalam pembelajaran statistika perbanyak latihan analisis data serta mengkaitkan pembacan hasil analisis data dengan variable/ masalah penelitian.

3) Mahasiswa yang sedang menyusun skripsi perlu dibantu dengan cara mengadakan pelatihan analisis data, dan metodologi penelitian.

4) Mahasiswa diberi kesempatan untuk memilih sendiri pembimbing yang diinginkannya, karena beragam salah satu faktor yang memungkinkan seorang mahasiswa tidak lulus dalam ujian skripsi, adalah ketidak seriusan dalam menyusun skripsi, akibat pelaksanaan bimbingan yang kurang intensif karena merasa tidak cocok dengan pembimbing.

\section{DAFTAR PUSTAKA}

[1] Baldwin, J. Hont. MP. 2001. Higher Education: Quality and Diversity in the 1990s. Canberra: Australia Government Publishing Service).

[2] Brennan, J. Delors. 2000. Managing Quality in Higher Education. (Buckingham: SRHE and Open University Press).

[3] Campanella, M. Pierre, and Simar, C. N. 2001. Definition of Quality of Service. New-York: SeQuin the National Research \& Education Network.

[4] Dirjen Dikti. 1996. Pedoman Pelaksanaan Penelitian dan Pengabdian Kepada Masyarakat Oleh Perguruan Tinggi. Jakarta: Lit-Bang Dikti.

[5] Fraenkel, Jack R, and Norman E. Wallen, 1993. How to Design and Evaluate Research in Education. Singapore: McGraw-Hill, Inc.

[6] Gagne, Robert, M. 1977. The Conditions of Learning. New York: Holt, Rinehart and Winston.

[7] Margaret L, Stephen. 2001. When a Survey Isn't Research. Washington, D.C: Brookings Institution.

[8] Mikkelsen, Britha. 1999. Metode Penelitian Partisipatoris dan Upaya-upaya Pemberdayaan, (terj.) Matheos Nalle .Jakarta: Yayasan Obor Indonesia.

[9] Nordholt N.G. Schulte dalam M.M. Billah. 1994. (edit) Metodologi Penelitian. Koreksi dan Pembenar an. Beberapa Masalah Metodologis di Seputar Penelitian Lapangan. Jakarta: CV. Rajawali.

[10] Race, Phil.1995. Research Teaching and Learning in Higher Education. London: Kogan Page Ltd.

[11] Piper, D. Bourke. 1999. Quality Management in Univer sities. Canberra: Australian Government Publishing Service 